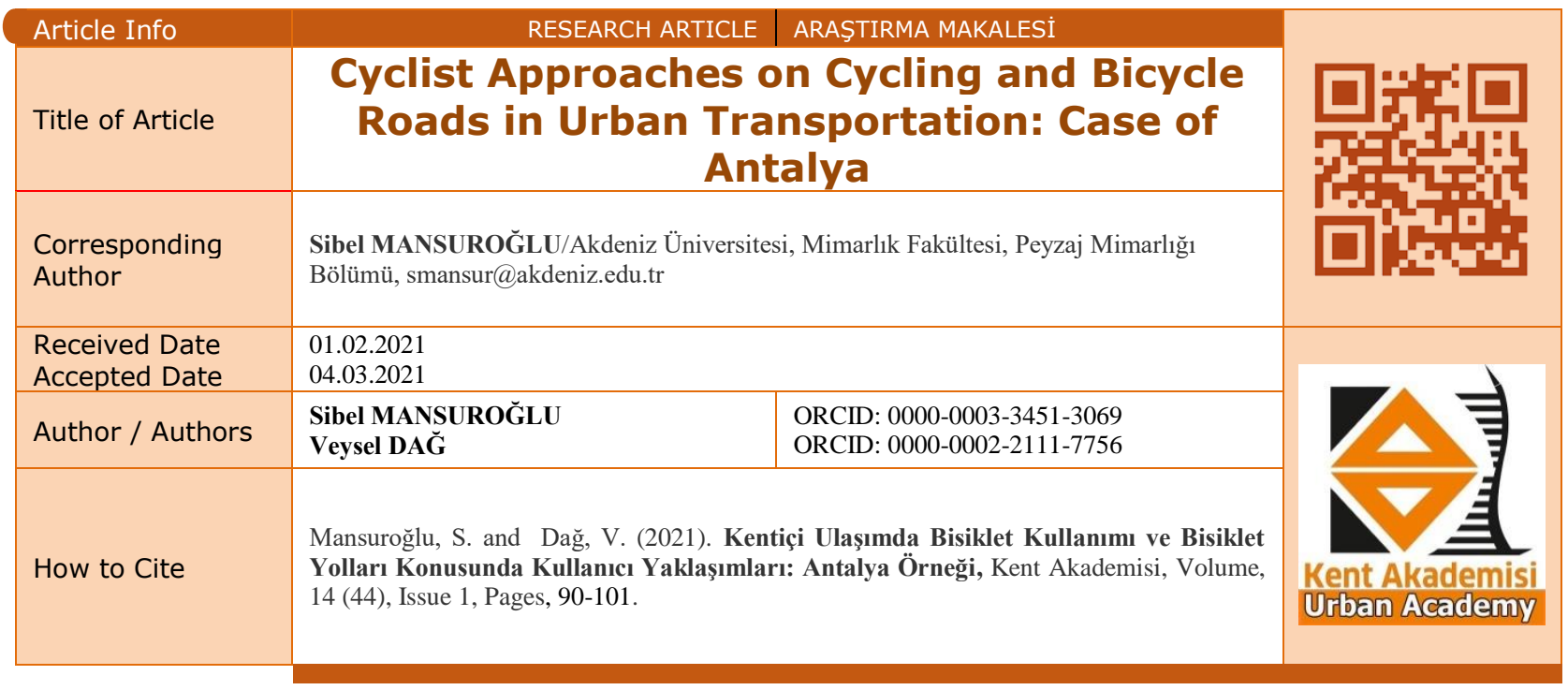

\title{
Kentiçi Ulaşımda Bisiklet Kullanımı ve Bisiklet Yolları Konusunda Kullanıcı Yaklaşımları: Antalya Örneği
}

Prof. Dr. Sibel MANSUROĞLU ${ }^{1}$ Arş. Gör. Veysel DAĞ ${ }^{2}$

\begin{abstract}
:
Due to the increasing environmental problems in the world, interest in the use of non-motorized vehicles has increased in recent years. Among these vehicles, the bicycle stands out with its economic and ecological benefits. However, despite this, the lack of adequate infrastructure in many countries is a factor that limits the use of bicycles. The aim of this study is to examine and evaluate the studies carried out to improve transportation by bicycle in Antalya city center, to determine the problems faced by bicycle users, and to put forward some suggestions for encouraging and developing bicycle use in line with the opinions and suggestions of bicycle users. The aim of this study is to examine and evaluate the studies carried out to improve transportation by bicycle in Antalya city center, to determine the problems faced by bicycle users, and to put forward some suggestions for encouraging and developing bicycle use in line with the opinions and suggestions of bicycle users. In the first stage of the study, the use of bicycles in urban transportation in Antalya, planning and applications for bicycles, spatial development and population characteristics that affect bicycle use, studies on the subject of the research were presented. In the second stage of the study, the individuals who use bicycles were interviewed with the questions prepared beforehand. At the last stage of the study, the problems of bicycle transportation in Antalya city were evaluated and some suggestions were made to eliminate the problems. As a result, it was emphasized that the rate of cycling is low in Antalya city center, which has a young and educated population, and this may be due to the inadequacy of education, the existence of problems arising from motor vehicle traffic, lack of knowledge and experience, and the inability to participate in sports activities.
\end{abstract}

KEYWORDS: Sustainable transportation, bicycle, qualitative research, Antalya.

\footnotetext{
${ }^{1}$ Akdeniz Üniversitesi, Mimarlık Fakültesi, Peyzaj Mimarlığı Bölümü, 07058, Antalya, smansur@akdeniz.edu.tr

${ }^{2}$ Pamukkale Üniversitesi, Mimarlık ve Tasarım Fakültesi, Peyzaj Mimarlı̆̆ı Bölümü, 20160, veyseldag@ windowslive.com
} 
öz:

Dünyada artan çevre sorunlarına bağlı olarak son yıllarda motorsuz araç kullanımına yönelik ilgi artmaktadır. Bu araçlar içerisinde ekonomik ve ekolojik faydaları ile bisiklet öne çıkmaktadır. Bisiklet günümüzde kentlerde ulaşımı sağlamanın en uygun yollarından biri kabul edilmektedir. Ancak buna rağmen birçok ülkede altyapı olanaklarının yetersiz olması bisiklet kullanımını sınırlandıran önemli bir faktör olarak görülmektedir. Bu çalışmanın amacı Antalya kent merkezinde bisiklet ile ulaşımın geliştirilmesi için yapılan çalışmaların incelenmesi ve değerlendirilmesi, bisiklet kullanıcılarının karşılaştı̆̆ı sorunların belirlenmesi ve bisiklet kullanıcılarının görüş ve önerileri doğrultusunda bisiklet kullanımının özendirilmesi ve geliştirilmesine katkı sağlayacak bir takım önerilerin geliştirilmesidir. Çalışmanın ilk aşamasında araştırma konusuna yönelik yapılan çalışmalar, Antalya'da kent içi ulaşımında bisiklet kullanımı ile bu konuda yapılan planlama ve uygulamalar, bisiklet kullanımına etki eden mekansal gelişim ve nüfus özellikleri ortaya konulmuştur. Çalışmanın ikinci aşamasında önceden hazırlanan sorularla, bisiklet kullanan bireylerle karşılıklı görüşme yapılmıştır. Çalışmanın son aşamasında Antalya kenti özelinde bisikletli ulaşım sorunları değerlendirilmiş ve sorunların ortadan kaldırılmasına yönelik bazı öneriler getirilmiştir. Sonuç olarak planlama ve tasarım çalışmalarında önemli yere sahip katılımcı yaklaşım düşüncesiyle bisiklet kullanıcıları ile yapılan genç ve eğitimli bir nüfusa sahip olan Antalya kent merkezinde bisiklet kullanım oranının düşük olduğu, bunun eğitimin yetersizliği, motorlu taşıt trafiğinden kaynaklı sorunların varlığı, bilgi ve tecrübe eksikliği ile spor etkinliklerine katılma yetersizliğinden kaynaklanabileceği vurgulanmışırı.

ANAHTAR KELIMELER: Sürdürülebilir ulaşım, bisiklet, nitel araştırma, Antalya.

\section{"Kentiçi Ulaşımda Bisiklet Kullanımı ve Bisiklet Yolları Konusunda Kullanıcı Yaklaşımları: Antalya Örneği"}

\section{GİRIŞ:}

Ulaşım, insan veya diğer canlı ve cansız objelerin bir yerden başka bir yere olan hareketi ile yapmış olduğu yer değiştirme olayıdır. İnsanların yerleşik hayata geçmesi ile önem kazanan ulaşım, teknolojinin gelişmesi ve ihtiyaçlar doğrultusunda zamanla çeşitlenmiştir. Elker (1999)'e göre ekonomik, sosyal ve kültürel yaşamın ayrılmaz bir elemanı olan ulaşım, gerek ülke çapında gerekse kent çapında diğer etkinlikler ile karşılıklı etkileşim halindedir. Sanayi devrimi ile birlikte üretim boyutlarının büyümesi sonucu tarım ve yerel işletmeciliğin yerini çok sayıda işçinin çalıştığı endüstriyel üretime bırakması, çalışanların konutlarından işyerine erişebilmesini gerekli kılması ise "kent içi ulaşım ihtiyacı"nı doğurmuştur (Öncü, 1997).

Ulaştırma Özel İhtisas Komisyonu (1995) ulaşımı, yaya ve bisiklet, bireysel (otomobil veya taksi ile), lastikli tekerlekli toplu taşım, raylı toplu taşım, deniz yolu ve yük taşımaları olmak üzere 6 sınıfta ele almaktadır. Kent içi ulaşım türleri içinde enerjiyi en verimli kullanan ve çevreyi en az kirleten ulaşım biçimi olmasına karşlık, ülkemizde bisikletin ulaşım amacıyla kullanımı çok sınılıdır (Yeşil ve Beyli, 2018; Mansuroğlu ve Dağ, 2020). Ülkemizdeki kentlerde bisiklet kullanım oranları veya bisiklet alt yapı sistemleri ile ilgili ayrıntılı bilgiye ulaşmak oldukça zordur. Ancak KENTGES (2010) stratejileri çerçevesinde (Strateji 5.2) kent içi ulaşımda, yaya ulaşımı ve bisiklet kullanımının kabul edilmiş tasarım ilkeleri doğrultusunda geliştirilmesi sağlanacaktır ifadesine yer verilmiştir. Bu çalışma ile Çevre ve Şehircilik Bakanlığı yerel yönetimlerin ve diğer paydaşların (Çevre ve Şehircilik İl Müdürlükleri, Kültür ve Turizm Bakanlığı) bisiklet altyapısının geliştirilmesine yönelik uygulamalarını Faaliyet/Çalışma Raporu şeklinde derlemektedir. Bu kapsamda "İyi Uygulamalar" başlığıyla sunulan 24 rapordan erişime açık olan 21'i incelenmiştir. 2010-2023 hedefleri doğrultusunda Yalova Belediyesi 2012 yılında $20 \mathrm{~km}$ bisiklet yolu; Trabzon Belediyesi 2010-2011 yıllarında $1 \mathrm{~km}$ bisiklet yolu ve Kocaeli Büyükşehir Belediyesi ise 2014 yılı sonuna kadar hedeflediği 10 km'lik bisiklet yolunun 6 km'sini 2011'de tamamladığını rapor etmiştir. Bununla birlikte 2019-2023 yıllarını kapsayan 11. Kalkınma Planında (2019) 2018 yılında ülke çapında toplam 1048 km bisiklet yolu uzunluğundan bahsedilmektedir.

Yüz yılı aşkın bir süre boyunca önemli ulaşım aracı olan bisiklet, bu önemini otomobil icat olana kadar devam ettirmiştir. Otomobillerin yaygınlaşması ile yollara egemen olan otomobiller bisikletlerin yerini almıştır. Bazı ülkelerde bisikletler neredeyse yok olma noktasına gelirken, bazı ülkelerde ise otomobiller ile aynı anda var olabilmişlerdir (Mansuroğlu ve Dağ, 2020). 
Küresel ısınma ve iklim değişikliğinin etkisinin daha fazla hissedilmesi ile motorlu taşıtlardan kaynaklanan hava ve gürültü kirliliği gibi çevre sorunlarının azaltılması amacıyla son yıllarda alternatif ulaşım araçlarına yönelik çalışmalar hız kazanmıştır. Bunun bir sonucu olarak günümüzde kent içinde kısa mesafelerde motorlu taşıtlara oranla daha sağlıklı, ekonomik ve güvenli olması, doğrudan çevre kirliliğine yol açmaması, az enerji gerektirmesi ve belirli trafik koşullarında diğer ulaşım araçlarına göre daha hızlı ulaşım sağlaması açısından en uygun yollardan biri kabul edilen bisiklet ile ulaşım gittikçe yaygınlaşmaktadır (Lundberg ve Weber, 2014; Heinen ve ark., 2010). Birçok çalışma, çağdaş kentsel alanların çeşitli arazi kullanımlarına sahip daha yoğun yapılara dönüştürülmesinin araç kullanımını önemli ölçüde azaltabileceğini ve alternatif ulaşım araçlarının payını artıracağını önermektedir (Ewing ve Cervero, 2010; Van Wee, 2002; Stead ve Marshall, 2001).

Antalya'da nüfusun belirli merkezlerde yoğunlaşması ulaşım olanaklarının motorlu taşıtlarla sınırlandırılmasına yol açmıştır. Nüfus yoğunluğuna bağlı olarak artan trafik yoğunluğu da çevre kirliliklerinin artmasına neden olmaktadır. $\mathrm{Bu}$ durum kentsel alanlardaki trafik yoğunluğunun azaltılması için gerekli çalışmaların yapılmasını zorunlu kılmaktadır. Bu çalışmanın amacı Antalya kent merkezinde bisiklet ulaşımının geliştirilmesi için yapılan çalışmaların incelenmesi ve değerlendirilmesi, bisiklet kullanımına yaklaşımların sorgulanması, Antalya kentinde bisiklet kullanıcılarının karşılaştı̆̆ı sorunların belirlenmesi ve bisiklet kullanıcılarının görüş ve önerileri doğrultusunda bisiklet kullanımının özendirilmesi ve geliştirilmesi yönünde bazı önerilerin ortaya konulmasıdır.

\section{MATERYAL ve YÖNTEM:}

Araştırma alanı, Konyaaltı, Muratpaşa, Kepez, Döşemealtı ve Aksu ilçelerini içerisine alan Antalya kent merkezidir (Şekil 1). Araştırmanın amacına uygun olarak, değişik aşamalarda analiz ve değerlendirme çalışmalarının yapılabilmesi için Antalya Büyükşehir Belediyesi ve Merkez İlçe Belediyeleri’nden plan, proje raporları ile ilgili diğer kurumlardan elde edilen her türlü bilgi ve belge, TÜiK'den elde edilen nüfus özellikleri ve diğer sosyo-ekonomik veriler çalışmada materyal olarak kullanılmıştır. Antalya kentsel yerleşim alanında ikamet eden bisiklet kullanan bireylerin bisikletli ulaşıma yönelik yaklaşımlarının saptanmasında kullanılan karşılıklı görüşme kılavuzları ile verilerin değerlendirilmesinde kullanılan SPSS ve Microsoft Excel programları da araştırmada kullanılan diğer materyallerdir.

Antalya kent merkezinde bisiklet kullanıcılarının bisikletli ulaşım konusundaki yaklaşımlarını saptamak amacıyla yapılan araştırma, arazi ve ofis olmak üzere iki yönde ve üç aşamalı olarak yürütülmüştür. Araştırmanın ilk aşamasında araştırma konusu ve alanına yönelik veriler toplanmıştır. Bu aşamada araştırma alanı olan Antalya'da kent içi ulaşımında bisiklet kullanımı, bisiklet için planlama ve uygulamalar, ülkemizdeki bisiklet yolu uygulamaları, Antalya'da bisiklet kullanımını etkileyen mekansal gelişim, nüfus özellikleri, toplu ulaşım olanakları ve bisiklet yollarına yönelik yapılan çalışmalar, konuyla doğrudan ilgili Antalya kent merkezini kapsayan plan, proje ve raporlar incelenmiştir. İkinci aşamada, bisiklet kullananların görüşlerini belirlemek amacıyla bisiklet kullanan bireylerle karşılıklı görüşmeler yapılmıştır. Bu aşamada önceden hazırlanan ve kent içinde bisiklet kullanımının olumlu ve olumsuz yanları, bisiklet kullanıcılarının yaşadıkları belli başlı sorunlar, Antalya'nın doğal peyzaj özellikleri ile bisiklet kullanımı arasındaki ilişkiler, mevcut bisiklet yolları ve kent halkının bisikletli ulaşıma yaklaşımları hakkındaki görüşleri gibi konuları içeren, 8 adet yapılandırılmış soru ile karşılıklı görüşme yapılmıştır.

Karşı1lıklı görüşmeler derinlemesine ve detaylı bilgi elde edilmesi ile bireylerin duygu, düşünce, tecrübe, eğilim gibi kişisel özelliklerini yansıtması açısından önemlidir. Plancı ve tasarımcıların katılımcılık ilkesi doğrultusunda bu görüşleri belirlemesi ve elde ettikleri bilgileri çalışmalarına yansıtması değer taşımaktadır. Çalışma alanı ve konusu ile ilgili yeterli veri elde edilmesi sonucu sorular yapılandırılarak, ilgili gönüllü kuruluşlar belirlenmiştir. Belirlenen bu kuruluşlarda gönüllü olarak faaliyet yürüten, konuyla doğrudan ilgili, sınırlı sayıda kişi (30 kişi) ile görüşme yapılmıştır. Görüşmede, verilerin değerlendirilmesinde elde edilen sonuçların daha sistematik belirlendiği, konuşma metinlerinin yazıya döküldüğü ve alınan cevapların sınıflandırıldığı betimsel ve sistematik analiz yöntemi kullanılmıştır. Çalışmanın amacı doğrultusunda bir çerçeve oluşturulmuş ve buna göre veriler işlendikten sonra bulgular tanımlanmış ve yorumlanmıştır. Böylece Antalya kent merkezinde bisikletli ulaşım mevcut bisiklet yolları özellikleri, çevresel etkiler, alan kullanımları, trafik ve kullanıcı özellikleri ve ilgili yasalar kapsamında bazı sonuçlara ulaşılmış, bisikletin bir ulaşım aracı olarak yaygınlaştııılması konusunda katkı sağlayacak önerilerin oluşturulmasına çalışılmıştır. Yapılandırılmış olan bireysel karşılıklı görüşme soruları aşağıdaki başlıklar altında oluşturulmuştur.

Title of Your Article

Journal of Urban Academy | Volume: 14 Issue: 1

ISSN: $2146-9229$

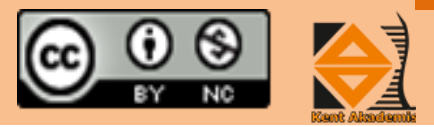




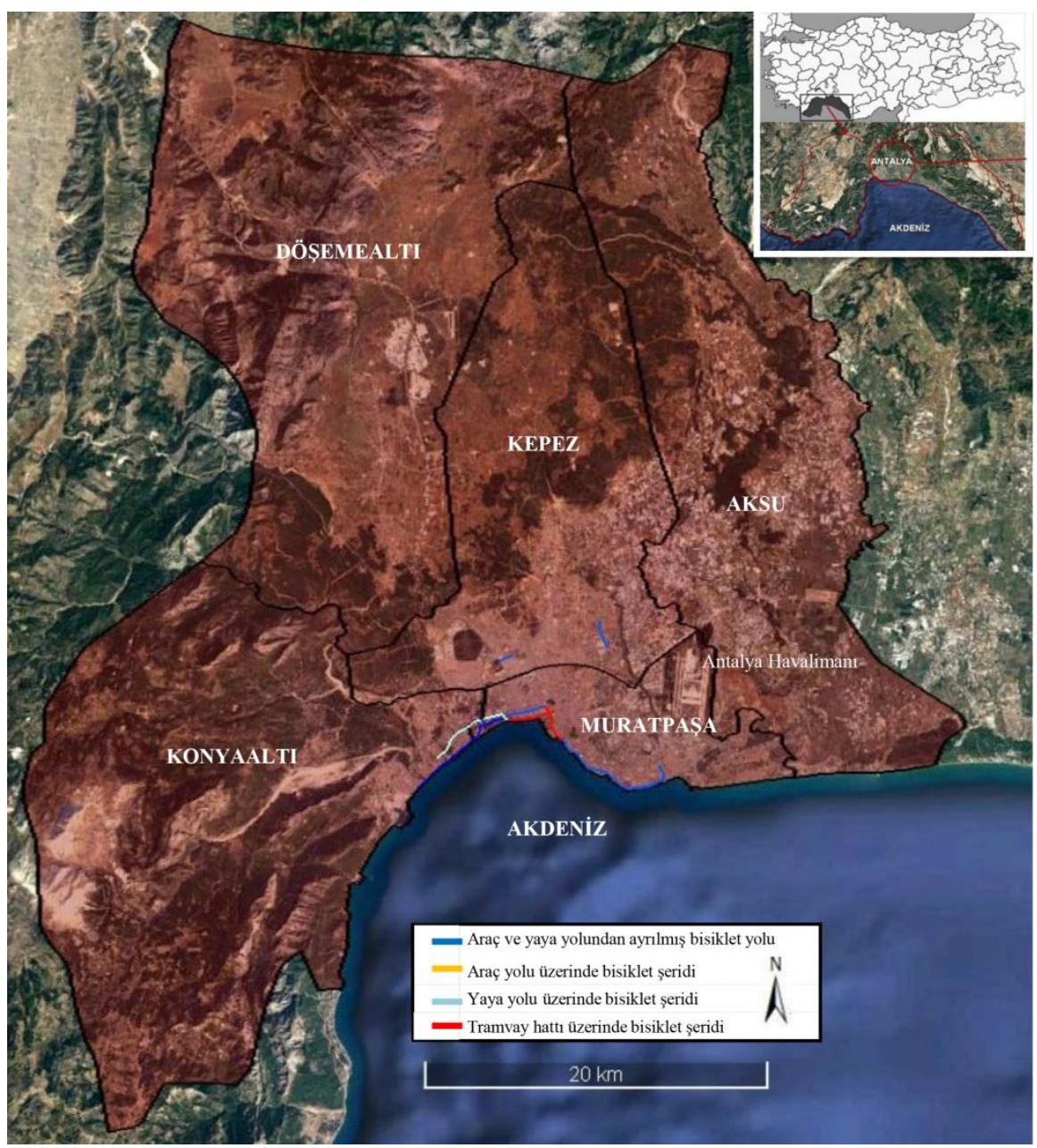

Şekil 1. Çalışma alanının coğrafi konumu ve Antalya kent merkezindeki bisiklet yolları (Google Earth 2021).

Açılıș soruları: Görüşme yapılan kişiyi tanıtıcı sorular.

Tanıtma soruları: Bisikletli ulaşıma yönelik genel sorular (görüşme yapılan kişinin konu ile bağlantısını kurmak amaçli).

Geçiș soruları: Bisikletli ulaşımın kent içindeki kullanım alışkanlıklarına yönelik sorular.

Anahtar sorular: Ülkemizde ve Antalya'da bisikletli ulaşımın değerlendirilmesi soruları.

Araștırma soruları: Antalya kent merkezindeki bisikletli ulaşım uygulamalarına yönelik sorular.

Kapanıș sorusu: Geleceğe yönelik önerilerin belirlendiği soru.

Final sorusu: Görüşme yapılan kişinin eklemek istediği konunun varlığının saptandığı soru.

Son olarak elde edilen tüm veriler değerlendirilerek, Antalya kent bütününde bisiklet kullanımının özendirilmesi ve geliştirilmesi yönünde çeşitli öneriler geliştirilmiştir. 


\section{BULGULAR:}

\subsection{Araştırma alanına yönelik bilgiler}

Bu bölümde araştırma alanı olan Antalya'da kent içi ulaşımında bisiklet kullanımını etkileyen mekansal gelişim, nüfus özellikleri, toplu ulaşım olanakları ve bisiklet yollarına ilişkin bilgiler özetlenmiştir.

- Mekansal Gelişim: Antalya kent merkezinde ulaşım ağları yerleşim alanlarına bağlı olarak şekillenmektedir. Kentin ilk yerleşim alanlarında yapı yoğunluğuna bağlı olarak dar olan yollar yeni yerleşim alanlarında genişlemiş, çevre yolları ile bunlara bağlı açılan bulvarlar kentin gelişimini yönlendirmiştir. Kentin yapılaşma hızının yüksek olması sonucu açılan çevre yolları zamanla kent içi ulaşımı sağlayan bulvarlara dönüşmüş (Gazi Bulvarı gibi), yeni çevre yolları açılmıştır. Tüm bu gelişmelerde ağırlıklı olarak motorlu taşıt trafiği dikkate alınmış, ulaşım ağları bunlara bağlı oluşturulmuştur. Aksu-Döşemealtı-Kepez-Muratpaşa-Konyaaltı-Serik İlçeleri 2040 yılı 1/25.000 Ölçekli Nazım İmar Planı Açıklama Raporuna göre Kaleiçi’nin büyük bölümünü içine alan kent merkezindeki yerleşim alanları geliştikleri dönemin özelliğine göre organik ve dar bir yol sistemine sahiptir. Günümüzde bu bölgedeki yollar genellikle yaya ulaşımı ve turizm odaklı şekillenmiştir. Kıyıdaki sahil şeridi boyunca gelişmiş olan kentsel yerleşimler ana yollara bağlı olarak kuzeye kaymıştır (ABB, 2017a). Kentin, Kaleiçi ve çevresini kapsayan ilk imar planında Bahçelievler gibi yerleşimler plan dışı kalmış, ardından yapılan çalışmalarda kent gelişimi batıya kaydırılmış, Lara kıyı bandı doğal sit olarak tanımlanmış ve bu bölgede yapılaşma sınırlı tutulmuştur (UTTA, 1996). Bisikletli ulaşım açısından önem taşıyan, turizm alanları, Antalya kent merkezi etkileşim alanında bulunan ilgili bakanlıkların yetkisi altında özel kanunlara bağlı Turizm Merkezleri (TM), Kültür Turizm Koruma ve Gelişim Bölgeleri (KTKGB) ile Özel Çevre Koruma Alanları (ÖÇK) bulunmaktadır. Bunlara ek olarak hemen hemen tüm yıl insan yoğunluğu dikkat çekici boyutlara ulaşan diğer turizm tesisleri ile park ve diğer rekreasyon alanları Konyaaltı ilçesinde sahil çevresi ile Muratpaşa ilçesinde falezler üzerinde yoğunlaşmaktadır (Antalya Çevre ve Şehircilik İl Müdürlügü̈, 2016; Antalya İl Kültür ve Turizm Müdürlüğü, 2018).

- Nüfus Özellikleri: İlk nüfus sayımının yapıldığ 1927 yılından itibaren Antalya ilinin nüfus gelişimi izlendiğinde, turizm ve tarım etkinliklerine bağlı olarak artan göçlerle 1970'li yıllardan itibaren kentli nüfusun arttığ görülmektedir. Antalya ili, özellikle de kent merkezi 1970'li yıllardan bu yana ülkemizin net göç hızı en yüksek illeri arasında yer almaktadır. Genel Nüfus Sayımı sonuçları (1980-2000) ve Adrese Dayalı Nüfus Kayıt Sistemi sonuçları (2007-2018) incelendiğinde 1985-1990 döneminde \%89,7 olan net göç hızının halen aynı şekilde devam etmesi dikkat çekmektedir. Ülkemizin nüfus büyüklüğü açısından beşinci kenti olan Antalya'da, 2018 yılı adrese dayalı nüfus verilerine göre 1222086 erkek, 1204270 kadın olmak üzere toplam 2426356 kişi yaşamaktadır. Araştırma alanında bulunan ilçelerden Aksu (35 adet), Döşemealtı (33 adet), Kepez (66 adet), Konyaaltı (39 adet) ve Muratpaşa'da (56 adet) toplam 229 adet Antalya Büyükşehir Belediyesi’ne bağlı mahalle bulunmaktadır. Bu ilçelerden Kepez (519 966 kişi) en fazla, Döşemealtı ise (59 948 kişi) en az nüfusa sahiptir (ADNK, 2019).

- Toplu Ulaşım Olanakları ve Bisiklet Yolları: Antalya, Türkiye'nin temel trafik akslarının dışında olmasına rağmen turizm ve tarım sektöründeki önemi nedeniyle motorlu taşıt trafiğinin yoğun olduğu bir merkezdir. Ulaşım, ağılıklı olarak kara ve hava yolu ile sağlanmakta olup, yük ve yolcu taşımacıllğında, havayolları ile gelen yolcuların turizm merkezlerine dağılımı da düşünüldüğünde, en önemli pay karayollarına aittir. Türkiye İstatistik Kurumu'nun (TÜíK) 2018 yılı Motorlu Kara Taşıtları İstatistiklerine göre Antalya'da trafiğe kayıtlı toplam 1 milyon 62 bin 419 taşıtın $\% 46,9$ 'unu otomobil, $\% 26,4$ 'ünü motosiklet, $\% 17,3$ 'ünü kamyonet, $\% 4,6$ 'sını traktör, $\% 2,2$ 'sini kamyon, \%1,4'ünü minibüs, \%1'ini otobüs, \%0,2'sini ise özel amaçlı taşıtlar oluşturmaktadır (TÜIK, 2019). Antalya Ulaşım Ana Planı (2017)'na göre Kaleiçi Bölgesi'nde yayalaştırma projeleri etkin bir şekilde uygulanmakla birlikte, genelde motorlu taşıt trafiğindeki artış yaya yolculuklarını azaltmıştır (ABB, 2017b). Kaleiçi ile bütünleşen Cumhuriyet Meydanı çevresi ile Kapalı Yol olarak bilinen cadde kent merkezindeki yaya ağını kuzeye yönlendirmektedir (ABB, 2017b).

2013 yılında açılan hibe programlarına Antalya Büyükşehir Belediyesi’nin başvurusunu yaptığı "Antalya Bisiklet Sistemi (ANTBİS)" isimli proje kabul edilmiştir. Proje kapsamında ilk aşamada; 6 istasyonda 40 bisiklet ve bisiklet park yeri yapılmıştır. ANTBİS Abone Kartı ve kredi kartlarıyla kullanım olanağının yer aldığı bu sistemde kullanıcıların istasyonlardan aldıkları bisikletleri diğer istasyonlara bırakabilmesi ile bisiklet kullanımının sağlanması planlanmıştır. Proje kapsamında Konyaaltı Kent Meydanı, Atatürk Parkı, Kapalı Yol, Büyükşehir Belediyesi, Sampi Kavşağı ve Düden Park olmak üzere 6 adet istasyon oluşturulmuştur (ABB, 2013). 2016 yılında yapılan 5 merkez 
ilçede bulunan tüm bisiklet yollarına yönelik saha çalışmalarında sorun saptanmış ve mevcut şebekenin tamamına yönelik yapılması planlanan projelendirme çalışmalarının altlıkları oluşturulmuştur (ABB, 2016).

\subsection{Karşılıklı görüş̧me sonuçlarının değerlendirilmesi}

Karşılıklı görüşmeler ile Antalya kent merkezinde bisiklet kullanım sorunlarının daha kapsamlı ortaya konulması amaçlanmıştır. Bu amaçla yapılandırılmış sorular kullanılarak, ulaşımda aktif bisiklet kullanan ve/veya bisiklet kullanımının yaygınlaştırılması konusunda gönüllü olarak çalışan 30 kişi ile bireysel olarak görüşme yapılmıştır. Cevapların denetimi ve değerlendirme kolaylığı sunması nedeniyle yapılandırılmış sorular kullanılmıştır. Karşılıklı görüşme formları bireylerin özellikleri ile kent içerisinde bisikletli ulaşımda yaşanan sorunların belirlenmesi kapsamında iki başlık altında oluşturulmuştur.

Karşılıklı Görüşmeye Katılanların Özellikleri: Karşılıklı görüşmeye katılanların 29'u erkek, 1'i kadındır. En küçük katılımcı 19, en büyük olan ise 56 yaşındadır. Katılanların \%53,3'ü evli, \%46,7'si ise bekardır. Görüşülen kişiler büyük oranda memur $(\% 53,3)$ olup, öğrenci $(\% 26,7)$, emekli $(\% 10,0)$ ve özel sektörde çalışanlar $(\% 10,0)$ da bulunmaktadır (Çizelge 1). Üniversite mezunlarının oranı \%36,7 iken, lise mezunları \%23,3; yüksek lisans mezunları $\% 16,7$; doktora mezunları \%13,3 ve yüksekokul mezunları \%10,0 oranındadır. En düşük gelire sahip olan ayda 1.000 TL gelire sahip iken, en yüksek gelire sahip olanın hane geliri aylık 18.000 TL'dir.

Çizelge 1. Karşılıklı görüşmeye katılanların sosyo-ekonomik durumu.

\begin{tabular}{|c|c|c|c|c|c|c|c|}
\hline Yaş & Oran (\%) & İş & Oran (\%) & Ĕgitim düzey & Oran $(\%)$ & Gelir* (TL) & Oran (\%) \\
\hline $19-24$ yaş & 26,7 & Öğrenci & 26,7 & Lise & 23,3 & 2.000 'den az & 26,7 \\
\hline $25-34$ yaş & 23,3 & Memur & 53,3 & Yüksekokul & 10,0 & $3.001-4.000$ & 10,0 \\
\hline $35-44$ yaş & 20,0 & Emekli & 10,0 & Üniversite & 36,7 & $4.001-5.000$ & 20,0 \\
\hline 45-56 yaş & 30,0 & Özel Sektör & 10,0 & Y. Lisans & 16,7 & $5.001-6.000$ & 16,6 \\
\hline * Çalışmanin y & dığ $\mathrm{l}$ dönemd & ABD Dolarl: & $.40 T L$ & Doktora & 13,3 & $6.001+$ & 26,7 \\
\hline
\end{tabular}

Karşılıklı görüşme yapılan kişilerin \%36,7'si 10 yıldan fazla süre ile Antalya'da yaşamaktadır (Şekil 2). Görüşülen kişilerin \%13,3'ü Antalya'da doğup büyüdüğünü belirtmiştir. İstanbul'dan gelen 6 kişi, Adana ve Ankara'dan 4'er kişi, İzmir, Denizli ve Muğla'dan 2'şer kişi, Eskişehir, Erzurum, Hatay, Mersin ve Van'dan 1'er kişi bulunurken, 1 kişi de yurtdışında yaşadıktan sonra 20 yıldır Antalya'da yaşadığını belirtmiştir. Diğer şehirlerden gelenlerin \%60’ı iş gereği, \%30’u eğitim amaçlı geldiklerini \%10’u da zaten Antalya'da yaşadığını ifade etmiştir.

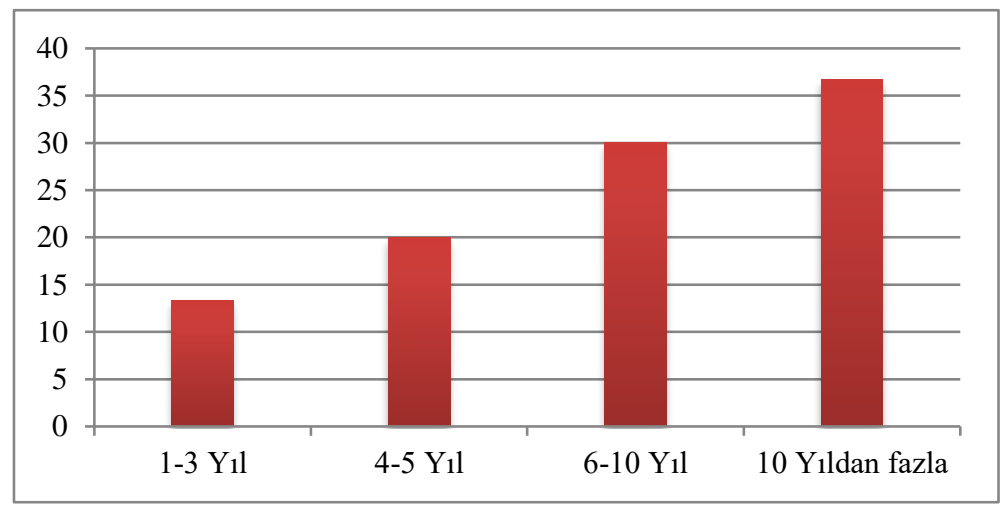

Şekil 2. Karşılıklı görüşmeye katılanların Antalya'da bulunma süreleri (\%).

Çalışmaya katılanların \%26,7'si hiçbir topluluğa üye olmayıp, \%50'si 1-3 yıl, \%6,6'sı 4-5 y1l, \%13,3'ü 6-10 yıl ve $\% 13,3$ 'ü ise 10 yıldan fazla süre boyunca bir toplulukta yer almaktadır. Akdeniz Üniversitesi Bisiklet Topluluğu (AKÜBİT)'nda bulunanlardan $(\% 23,3)$ topluluk başkanı, topluluk başkan yardımcısı ve topluluk kurucu üyeleri ile görüşme yapılmıştır. Antalya Bisiklet Sevenler (ABS) Grubu (\%23,3)'ndan görüşülen kişilerden 2'si yönetim ekibinde, diğerleri ise üyedir. Antalya Bisiklet Derneği (ANTBİSDER) kurucu başkanı, kurucu üyesi ve iki üyesi ile görüşülmüştür. Toroslar Doğa Sporları Klübü (TODOKS)'ne üye iki kişi, VELESPİT kurucularından kurucu ve başkanı ile Antalya Perşembe Akşamı Bisikletçileri Kurucularından 1 kişi ile görüşmeler yapılmıştır. 
Kent İçerisinde Bisikletli Ulaşımda Yaşanan Sorunlar: Bu başlık altında kent içindeki bisiklet kullanım alışkanlıkları, ülkemiz kentlerinde bisiklet yolları oluşturulmasına yönelik görüşler, Antalya kent merkezinde bisiklet kullanımındaki sorunlar, kent içi ulaşımda bisiklet kullanımı için Antalya'da ve diğer kentlerimizde yapılan uygulamaların değerlendirilmesi, Antalya'daki mevcut bisiklet yollarının durumunun olumlu ve olumsuz yönleri, Antalya kent merkezinde bisiklet kullanımına yönelik öneriler ile bisiklet kullanımının özendirilmesi için yapılması gerekenler sorgulanmıştır.

Kent içindeki bisiklet kullanım alışkanlıkları: Bu başlık altında katılımcılar bisiklet kullanım süresi, kullanım amacı, Antalya'da bisiklet kullanım güzergahları ve kent içinde bisikletin bir ulaşım aracı olarak kullanımı hakkındaki görüşlerini belirtmişlerdir.

En az süre ile bisiklet kullanan 3 kişi Antalya'da 1 yıldır aktif olarak ulaşım amaçlı bisiklet kullandıklarını ifade etmişlerdir. En uzun süre kullanan kişi ise 25 yıldır Antalya'da ulaşımda bisiklet kullandı̆̆ını belirtmiş̧ir. Kullanıcıların \%23,3'ü 1-3 yıl, \%26,7'si 4-5 yıl, \%40'1 6-10 yıl ve \%10'u ise 10 yıldan fazla süre ile aktif bir şekilde Antalya'da ulaşımda bisiklet kullanmaktadır (Şekil 3).

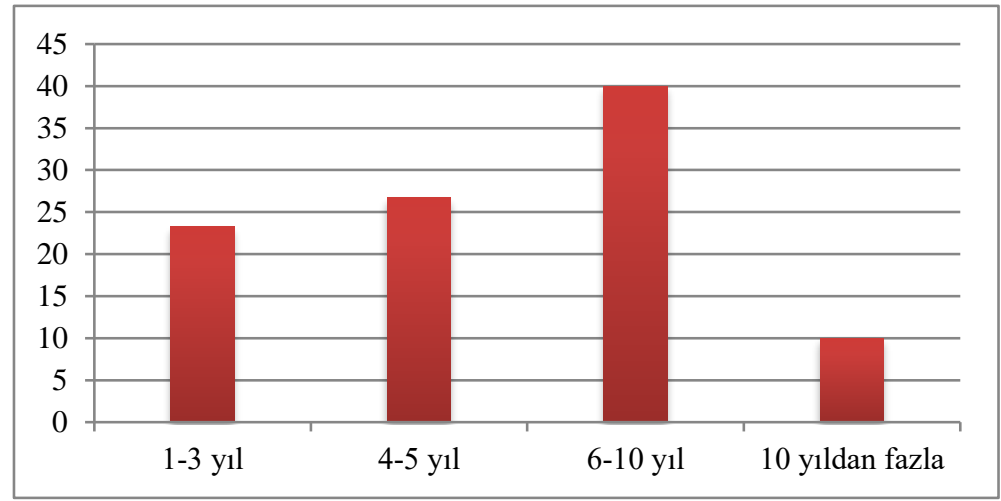

Şekil 3. Karşılıklı görüşmeye katılanların Antalya'da bisiklet kullanım süreleri (\%).

Bisiklet kullanım amaçları genel olarak kısa mesafelerde ulaşım amaçlı olup, spor ve sağlık amaçlı olanlar sahil ve kırsal alanlarda daha uzun mesafelerde kullanmaktadır. Aktif çalışma ve öğrenim hayatını sürdüren katılımcılar ev-iş ya da ev-okul arasında bisiklet ile ulaşım sağlamaktadır. Üniversitede çalışan ya da öğrenci olanlar ise üniversite yerleşkesi içerisinde ulaşım amaçlı bisiklet kullandıklarını ve bisikleti yaygın bir ulaşım aracı olarak kullandıklarını özellikle vurgulamışlardır. Antalya'da bisiklet kullanım güzergahları çok çeşitli olup, gezinti için kullananlar ağırlıklı olarak Konyaaltı sahili ile yakın çevredeki köyler ve kırsal alanları tercih etmektedir. Bunun dışında Konyaaltı ilçesi mahalleleri ile üniversite yerleşkesi arasında kalan bölge, Konyaaltı Caddesi, Gazi Bulvarı, Batı Antalya Çevre Yolu, Düden Park çevresi, EXPO yolu, Konyaaltı-Lara arası, kent merkezinde trafiğgin az yoğun olduğu sokaklar, üniversite yerleşkesi bisiklet kullanım güzergahlarıdır. Ayrıca spor amaçlı seçilen güzergahlar Bucak, Side, Kemer, Aksu, Döşemealtı ve Manavgat'tır. Kent merkezinde bölgesel olarak Konyaaltı, Kepez ve Lara en fazla kullanılan güzergahları kapsamaktadır.

Bisikletin kent içinde ulaşım aracı olarak kullanımına olumlu yaklaşan katılımcılar, bisiklet kullanımının yaygınlaştırılması için toplu taşıma ile birlikte düşünülmesi gerektiği üzerinde durmaktadır. Buna karşın mevcut durumda kent içinde bisiklet kullanımının riskli ve tehlikeli, motorlu taşıt sürücülerinin anlayışsız, bisiklet yollarının uzunluk ve altyapı olarak yetersiz, bisiklet hırsızlıklarının çok fazla olması gibi nedenler ile bisikletin ulaşım aracı olarak yaygın bir şeklide kullanılamadığını düşünmektedirler. Ancak bisikletin kent içinde kullanımının insan ve çevre sağlığına katkı sağlamak ve motorlu taşıt trafiğini azaltmak için yaygınlaştırılmasının önemli olduğunu vurgulamaktadırlar.

Ülkemiz kentlerinde bisiklet yolları olușturulmasına yönelik görüssler: Genel olarak bisiklet yollarının tekniğine ve standartlara uygun yapılmadığı, bisiklet yollarında kullanılan boyaların islak havalarda kaygan bir zemin oluşturduğundan tehlike yarattığı belirtilmiştir. Yerel yöneticilerin bisikletli ulaşım konusunda bilinçli olmadığı, bu nedenle göstermelik uygulamaların yapıldığı, bisiklet yolu genişliği, park alanı ve aydınlatmanın yetersiz, Title of Your Article 
güzergahların kesintili devam ettiği ve kavşak düzenlemelerinin bulunmadığı bireylerin diğer saptamalarıdır. Bisiklet güzergahları oluşturulurken bisiklet kullanıcılarının tercih ettiği yolların dikkate alınmaması, bisiklet yollarının yayalar ve diğer araçlar tarafından işgal edilmesi, kent içi ulaşımda motorlu taşıt trafiğine öncelik verildiğinden, bisiklet kullanıcılarının tehlike altında kalması ise dikkat çekilen diğer konulardır.

Antalya kent merkezinde bisiklet kullanımındaki sorunlar: Bisiklet kullananlar güvenli park alanları bulunmadığından, bisiklet hırsızlığının yaygınlığı ile motorlu taşıt sürücülerinin saygısız ve anlayışsız olmaları üzerinde durmuşlardır. Ayrıca mevcut bisiklet yollarının az ve kesintili olduğunu, yağmurlu havalarda kayganlaştığını, zeminin ondüleli olduğunu ve bisiklet yollarındaki mazgalların tehlike yarattığını belirtmişlerdir. Bisiklet yollarının motorlu taşıt trafiğinden tam olarak ayrılmadığına, yaya ve diğer araçlar tarafından kullanıldığına, toplu taşıma araçlarına bisiklet ile binilemediğine de işaret edilmiştir.

Kent içi ulaşımda bisiklet kullanımı için Antalya'da ve diğer kentlerimizde yapılan uygulamaların değerlendirilmesi: Katılımcılara göre Antalya'da sahil kesimi dışında bisiklet yolu uygulaması yaygın değildir. Kent içi ulaşımı sağlayacak bir ağ oluşturulmamıştır. Konyaaltı ve Lara'da yapılan yollar farkındalık yaratmakla birlikte yeterli değildir. Antalya'da iyi bir bisiklet yolu ağı oluşturulması kentin ulaşım sorununu çözmede etkili olabilecektir. Bisikletin ulaşım amaçlı kullanıldığı yollar trafik levhaları, elektrik direkleri, reklam panoları, mazgallar, engelli yürüyüş şeritleri vb. nedeniyle kullanıcı açısından tehlikelidir. Bisiklet güvenli park alanlarının olmayışı kent içindeki AVM, hastane, eğitim kurumları gibi mekanlara bisikletle ulaşmada bir sorun yaratmaktadır. Toplu taşıma araçlarına bisikletle binilememesi, raylı sistemin yaygın olmayışı bisikletin ulaşım aracı olarak kullanımını kısıtlayan diğer etkenler olarak belirtilmiştir. Kent içinde bisiklet kullananların yaşadığı sıkıntılar kadın ve çocukların bisiklet kullanımını engellemektedir. Daha çok genç erkekler bisiklet kullanmaktadır. Bisiklet yolları ile yaya yollarının çakışması tehlikeli bir durum yaratmaktadır. Mevcut koşullarda bisikletin ulaşım aracı olarak kullanılmaktan uzak olduğu düşünülmektedir. Yılın belirli dönemlerinde kentte yapılan bisiklet yarışları ve ANTBİS uygulaması istasyon ve bisiklet sayısı açısından yetersiz görülmekle birlikte bisikletin yaygınlaştırılması açısından olumlu görülmesine karşın, bisiklet kiralama noktalarına ulaşımın zor olduğu bildirilmektedir.

Antalya ilçelerindeki uygulamalardan Finike-Kumluca arasındaki bisiklet yolu taşıt yolundan ayrıldığı için emniyetli olarak tanımlanmaktadır. Marmaris ve Ortaca'daki uygulamalar motorlu araç görüşünün engellendiği ve kesintisiz olması nedeniyle beğenilmektedir. Mersin, İstanbul ve İzmir'de bisikletle toplu taşıma araçlarına binilebildiği, Konya'da ise güzergah seçimi, bisiklet yolu ağı oluşturulması ve bisikletin diğer ulaşım ağlarına entegre edilmesinin olumlu olduğu yönünde görüşler bildirilmektedir. Eskişehir, Konya ve Nevşehir'in diğer kentlere göre daha iyi uygulamalara sahip olduğu, Isparta ve Niğde’de yapılan uygulamalarda güzergah ve standartlara uygunluk açısından sorunlar olduğu ifade edilmektedir.

Antalya'daki mevcut bisiklet yollarının durumunun olumlu ve olumsuz yönleri: Katılımcılar genel olarak Antalya'daki bisiklet yollarını parçalı ve bağlantısız, genişlik açısından yetersiz, bazı alanlarda gereksiz olarak uzatılmış görmektedir. Bisiklet yollarının işaretleme ve sinyalizasyon ile park alanları açısından yeterli ve güvenli olmadığını, yaya ve motorlu taşıt trafiği ile karışmış, şehrin ana güzergahları ile uyumsuz bulduklarını ifade etmişlerdir. Ayrıca güzergahların ve bisiklet istasyonlarının kentin turistik alanları ile yeterince ilişkili olmadığını, Konyaaltı sahilindeki bisiklet yolunda kullanılan sarkıcı bitkilerin bisiklet kullananlar için tehlike yarattığını belirtmişlerdir. Mevcut bisiklet yollarının sadece belirli bölgelerde (Lara ve Konyaaltı) yoğunlaşması olumsuz görülürken, kent genelinde bisiklet yollarının yaygınlaştırılmasına yönelik çalışmalar olumlu değerlendirilmektedir.

Antalya kent merkezinde bisiklet kullanımına yönelik öneriler: Çalışmaya katılanlar bisikletlilerin trafikten korunmasının önemli olduğunu, bu amaçla bisiklet yollarının taşıt yollarından ayrılması gerektiğini vurgulamışlardır. Buna ek olarak bisiklet ile öncelikle belirli merkezlere kesintisiz ulaşımın sağlanması gerektiği, kaldırımlardaki bisiklet şeritlerinin yaya ve bisikletliler için uygun genişlik ve yapıya sahip olmadığı, üniversitede bisiklet kullanımının yaygın olmasına rağmen, üniversiteye bisiklet ile ulaşım sağlayacak uygun güzergahların bulunmadığını belirtmişlerdir. Ayrıca AVM, kamu kurumları, hastaneler ve üniversite gibi yoğun kullanıma sahip alanlara bisiklet ile ulaşım sağlanması gerektiği, okullarda bisiklet park alanları oluşturulması, genel olarak güvenli bisiklet park alanlarının yaratılması ve buralarda bisiklet bakım istasyonlarına yer verilmesi üzerinde de durulmuştur. 
Kullanıcılar yapmış oldukları gözlem, meslek disiplinlerinin gereği bulundukları konum ve çevrelerinden aldıkları duyum ile Antalya'da bisiklet yollarının öncelikli yapılması gereken bazı bölgeler için önerilerde bulunmuşlardır. Batı Antalya Çevre Yolu, Gazi Bulvarı, Yıldrım Bayezit Caddesi, Sakarya Bulvarı, Seyhan Caddesi, Süleyman Demirel Bulvarı, Vatan Bulvarı-Güllük bağlantısı, Fatih Caddesi, Yeşilırmak Caddesi, Sütçüler Caddesi, Aşık Veysel Caddesi, Yeni Hal Yolu, Ali Çetinkaya Caddesi, 100. Yıl Caddesi, Sampi Kavşağı-Lara Bölgesi (KL08 ve KL06 otobüs güzergahlarında), Yeni Sanayi Bölgesi (tramvay hattına aktarma istasyonu ile) gibi alanlar bisiklet yolu oluşturulması için uygun genişlikte olup, kent merkezi ile birçok kullanım alanına ulaşım sağlaması açısından öncelikli olarak bu caddeler üzerinde bisiklet yolu oluşturulması gerektiği konusunda görüş bildirilmiştir. Mevcut olanaklar çerçevesinde Kepez ilçesindeki Varsak Bölgesi’nden kent merkezine bisiklet ile ulaşımın sağlanmasının mevcut durumda çok zor olduğu ayrıca belirtilmiştir.

Kırsal bölge niteliğinde olan ve hafta sonları yoğun ziyaret edilen Çakırlar Bölgesi’ne bisiklet ile ulaşım sağlanarak, bölgenin doğal yapısının zarar görmesinin önüne geçilmesinde rol alacağı konusu önemli bulunmuştur. Turistik açıdan önemli olan turizm yolu-oteller bölgesinde de bisiklet yollarının standartlara uygun bir şekilde ve arttırılarak yapılması önerilmektedir. Kemer yolu bisikletliler tarafindan yoğun kullanılan bölge olduğu için, tünel geçişlerinde ve yol boyu güvenli sürüş sağlanmasının önem taşıdığı belirtilmiştir.

Bisiklet kullanımının özendirilmesi için yapılması gerekenler: Karşılıklı görüşmeye katılanlara göre bisiklet kullanımının yaygınlaşması için kamu kurumları ve özel sektör temsilcilerinin teşvik edici çalışmalar (prim, teşvik ücreti, hediye/kuruma ait bisiklet sağlama vb.) yapmasının rolü olabilir. Sağlıklı toplum için bisikletin avantajlarını açıklayıcı, bilgilendirme ve bilinçlendirme amaçlı kamu spotları hazırlanmalıdır. Bisiklet yarışları ve festivallerinin arttırılması ve medyada sürekli yer verilmesi ile farkındalık yaratılması önemlidir. Trafik denetlemelerinin arttırılması, bisiklet ile ilgili yasal düzenlemeler ile ilgili bilgilendirmeler yapılmalıdır. Bisikletli polis ve zabıta ekipleri oluşturulmalıdır. Kamu kurum çalışanları, özellikle önemli makamlarda bulunan kişilerin bisiklet kullanması ile farkındalık oluşturulmalıdır. Okullarda öğretmenlerin ve öğrencilerin bisiklet ile okula ulaşımını sağlayacak düzenlemeler yapılmalıdır. Emeklilere ücretsiz otobüse binme hakkı yerine ücretsiz bisiklet ve/veya bisiklet kiralama hizmeti sunulmalıdır. Bisiklet fiyatlarında KDV vb. indirim uygulanması ile bisiklet edinilmesine katkıda bulunulmalidir.

Çalışmaya katılanlar bireysel ve/veya üyesi oldukları topluluklar ile bisiklet kullanımının özendirilmesi için çeşitli bisiklet turları düzenlendiklerini; okullarda, halk eğitim merkezlerinde, yerel yönetimler ile işbirliği yaparak belediye kültür merkezlerinde tanıtıcı ve eğitici seminerler ve kurslar verdiklerini belirtmişlerdir.

\section{TARTIŞMA ve SONUÇ:}

Antalya iklimsel ve topografik özellikleri açısından bisiklet kullanımı için uygun doğal koşullara sahip olmasına rağmen, kentte bisiklet kullanım oranı oldukça düşüktür (Mansuroğlu ve Dağ, 2020). Antalya, bulunduğu coğrafi koşullar bakımından bisiklet kenti olmaya elverişli bir durumdayken, hali hazırda yapılmış olan uygulamalar bu konuda yetersizdir. Ulaşımda ağırlıklı olarak motorlu taşıt trafiği dikkate alınmış, ulaşım ağları bunlara bağlı oluşturulmuştur. Bisiklet yolları ile ilgili yapılan çalışmalarla Antalya genelinde belirlenen bazı bölgelere bisiklet ulaşımı için ayrı yollar düzenlemiştir. Ancak bisiklet yollarının toplu taşıma araçları ve yaya yolları ile bağlantısı kurulmamış olup, kentle bütünlüğü ya da devamlılığı da bulunmamaktadır. Mansuroğlu ve Dağ (2020) kent merkezinde insan yoğunluğunun dikkat çekici boyutlara ulaştığı alanlar ile kent halkı ve yerli/yabancı turistlerin günübirlik turizm bölgeleri, park alanları, rekreasyon alanları ile kent içerisinde ve yakın çevresinde bulunan koruma alanlarına bisiklet ile ulaşımın sağlanamadığını, bu alanlara uygun güzergahlar ile ulaşımın sağlanması durumunda alanların sürdürülebilirliğine ve turizme katkı sağlanabileceğini vurgulamışlardır.

Bisiklet yollarının kentlerde belirli odak noktalarına ulaşım sağlayacak biçimde planlanması gerekirken, Antalya'da mevcut bisiklet yolları ulaşım talebi olan sahil şeridi dışında ulaşım sağlayacak bütünlükte değildir. Sahil şeridinde bulunan bisiklet yolları da bütünleşik bir ağ oluşturmamaktadır. Bisiklet yol ağının kent içinde bütünleşik bir sistem oluşturmamasının en temel nedenlerinden biri kesintilere uğramasıdır. Mert (2007) Konya'da 215 km bisiklet yolu bulunduğunu, bunun toplu taşıma ile entegre olmasından dolayı insanların \%54,8 oranla ulaşım amaçlı bisiklet kullandığını tespit etmiştir. Zhao (2014) Pekin'de yapısal çevrenin bisiklet kullanımına etkisi üzerine yaptığı araştırmada ulaşım kolaylığı, uygun bisiklet altyapı sistemlerinin varlığı ve birbiri ile olan ilişkisinin bisiklet 
kullanımını arttırdığını ve uygun altyapı sistemlerinin yoğun yerleşim alanlarında da bisiklet kullanımını özendirdiğini vurgulanmıştır. Providelo ve Sanches (2010), Brezilya'da yol genişliği, araç hızı, kavşakların algılanabilirliği, kavşak yapısı ve yol ağaçlandırmasının (gölgeleme amaçlı) bisiklet kullanımını etkilediğini ortaya koymuşlardır. Buehler ve Pucher (2012), Amerika'da yolların fiziksel özellikleri (uzunluğu, genişliği vb.) ile kullanıcı sayısı arasında anlamlı bir ilişki bulunduğunu ve bu ilişkinin mevcut alan kullanım durumu, iklim, sosyo-ekonomik faktörler, akaryakıt fiyatları, şehir içi ulaşım olanakları ile güvenli bisiklet sürüş alanlarına bağlı olarak çeşitlendiğini ifade etmişlerdir.

Güvenli sürüş alanlarının yetersiz olduğunu her firsatta dile getiren kullanıcılar mevcut bazı bisiklet yollarında araçların park etmesi, elektrikli bisiklet ve geri dönüşüm materyali toplayan kişilerin bisiklet yollarını kullanmasının da bir takım sorunlara neden olduğunu belirtmiştir. Schepers ve ark. (2017) Hollanda'da 30 yılda bisiklet kazalarının \%80 oranında azaltılmasının, taşıt yoğunluğuna bağlı olarak hiyerarşik düzende oluşturulan sistemli ulaşım ağı, bisiklet yollarının araç yollarından ayrılması ve bisiklet kullanıcı sayısının arttırılması yönünde yapılan çalışmalar ile birlikte araç kullanıcılarının da duyarlılığının artmasına bağlı olduğunu vurgulamışlardır.

Antalyalı bisiklet kullanıcıları otobüs yolculuğu sırasında bisikletini yanında taşıyamamakta ve bisikletli yolculuk sürekliliğini sağlayamamaktadır. Otobüslerin yanı sıra Antray'la yapılan yolculuklarda bisiklet taşınamayacağı, Antalya Ulaşım A.Ş web sitesinde yer alan Antray yolculuk kuralları gereğinde belirtilmiştir. Bisiklet ulaşımı ile raylı sistem entegrasyonunu destekleyen durak yerleri belli başlı noktalarda kurulmuşsa da sistemin genelinde yetersiz kaldığı gözlenmiştir. Bu durumlar bisiklet sürücüleri için engel teşkil etmektedir. Yavuz (2016) İzmir'de 41 km'lik bisiklet yolunun toplu taşımaya entegre edilmesi amacıyla bisiklet kiralama sisteminin kurulduğunu aktarmaktadır. Kentteki 31 istasyonda 400 bisiklet, 600 bisiklet park alanının bulunduğu, böylece ulaşımda bisiklet tercih oranının arttığı belirtilmiştir. Araştırmacının 404 kişi ile yapmış olduğu anket çalışması sonucunda insanların \%25'inin bu sayede bisiklet ile ulaşımı tercih ettiğini ortaya koymuştur. Mansuroğlu ve Dă̆ (2019) Antalya kent merkezinde kentsel (400) ve kırsal (400) yerleşim birimlerinde yaşayan 800 kişi ile yapmış oldukları anket çalışmasında halkın \%31'inin bisiklet kullandığını, ancak bunun sadece \%2,9'unun ulaşım amaçlı olduğunu tespit etmişlerdir. Aynı çalışmada memur $(\% 27,9)$ ve öğrencilerin $(\% 22,3)$ bisiklet alt yapısının geliştirilmesi ile ulaşımda bisiklet kullanabileceklerini belirttikleri ifade edilmektedir. McBain ve Coulfield (2017) Cork (İrlanda) Kenti'nde özellikle otobüs veya raylı sistem ile bağlantısı olan bisiklet istasyonlarından aktarma yapmak amacıyla daha fazla yararlanıldığı, Sun ve Zacharias (2017) Pekin'de (Çin) kısa mesafelerde bisiklet ile otobüs veya raylı sistemlere aktarma yapılabilecek noktaları belirlemeye yönelik yapılan çalışmada 1,5-2 km ulaşım mesafesinden gelen yolcuların 2 ana aktarma istasyonu önerisinde bulunduğu sonucuna ulaşmışlardır.

Doğal ve kültürel peyzaj değerleri ile turistlerin ilgisini çeken Antalya'da, başta ulaşım olmak üzere yapılacak her türlü planlanma çalışmasında sürdürülebilirliğin sağlanması önemlidir. Bu bağlamda bu değerlere bağlı hareket edilmeli, ulaşım ağları ile diğer kullanımlar arasındaki ilişki ve çelişkiler değerlendirilerek, kentlerin ulaşım sorunlarının çözülmesinde halka sunulan ulaşım olanaklarının çeşitlendirilmesi, çevre ile dost sistemlerin geliştirilmesi, ekonomik ve hızlı ulaşımın sağlanmasına yönelik doğru kararların alınması önem taşımaktadır. Bu karaların alınmasında bu çalışmada olduğu gibi konu ile doğrudan ilgili kişilerin görüşlerinin alınması ile katılımcı planlama ve tasarımlara yer verilmelidir. Dünyada kentlerde artan ulaşım sorunlarının azaltılması yönünde bisikletin, sözü edilen olanaklar sunması nedeniyle öne çıkan bir ulaşım aracı olduğu dikkate alınarak, kent özelinde uygun planlama çalışmaları ile bisikletin mevcut ulaşım ağına entegre edilmesinin gerekliliği ortaya çıkmaktadır.

\section{Etik Standart ile Uyumluluk}

Çıkar Çatışması: Yazarlar herhangi bir çıkar çatışmasının olmadığını beyan eder.

Etik Kurul İzni: Bu çalışma Akdeniz Üniversitesi Fen ve Mühendislik Bilimleri Bilimsel Araştırma ve Yayın Etiği Kurulu tarafından (katılanların oy birliği ile) insandan görüşme yolu ile bilgi edinilebileceğine dair alınan etik kurul kararı (07/1 sayı ve 13.12.2017 tarihli) ile başlatılmıştır.

Finansal Destek: Bu çalışmayı Normal Araştırma Projesi (FBA-2018-3316) olarak destekleyen Akdeniz Üniversitesi Bilimsel Araştırma Projeleri (BAP) Koordinasyon Birimi’ne teşekkür ederiz.

Teşekkür: Bu çalışmayı Normal Araştırma Projesi (FBA-2018-3316) olarak destekleyen Akdeniz Üniversitesi Bilimsel Araştırma Projeleri (BAP) Koordinasyon Birimi’ne teşekkür ederiz. 


\section{KAYNAKÇA:}

ABB (2013). Antalya Büyükșehir Belediyesi 2013 Faaliyet Raporu. https://www.antalya.bel.tr/Content/UserFiles/Files/Raporlar\%2FFaaliyetRaporlari\%2F2013-faaliyet-raporu.pdf Erişim tarihi: 01.03.2019

ABB (2016). Antalya Büyükşehir Belediyesi 2016 Faaliyet Raporu. https://www.antalya.bel.tr/Content/UserFiles/Files/Raporlar\%2FFaaliyetRaporlari\%2F2016_antalya_buyuksehir_bele diyesi_faaliyet_raporu.pdf Erişim tarihi: 01.03.2019

ABB (2017a). Antalya Büyükșehir Belediyesi Aksu-Döşemealtı-Kepez-Muratpaşa-Konyaaltı-Serik İlçeleri 2040 yılı 1/25.000 Ölçekli Nazım İmar Planı Açıklama Raporu (Temmuz 2017).https://antalya.bel.tr/Content/UserFiles/Files/imar_plan_tadilat\%2FYUZBIN\%20RAPOR.pdf Erişim tarihi: 01.03.2019

ABB (2017b). Antalya Büyükşehir Belediyesi, 2040 Antalya Ulaşım Ana Planı, Antalya Ulaşım Ana Planı Yapılması Hizmet Alımı İ̧̧i Ulaşım Ana Planı Sonuç Raporu 5.2/6, Boğaziçi Proje Mühendislik A.Ş.

ADNK (2019). Adrese Dayalı Nüfus Kayıt Sistemi. http://biruni.tuik.gov.tr/medas/?kn=95\&locale=tr Erişim tarihi: 01.03.2019

Antalya Çevre ve Şehircilik İl Müdürlüğü (2016). Antalya İli 2015 Yılı Çevre Durum Raporu. T.C. Antalya Valiliği $\begin{array}{lllllll}\text { Çevre ve Şehircilik İl Müdürlüğü. } & \text { Erişim } & \text { tarihi: } & 01.03 .2019\end{array}$ https://webdosya.csb.gov.tr/db/ced/editordosya/Antalya\%20cevre\%20durum\%20raporu\%202015.pdf

Antalya İl Kültür ve Turizm Müdürlüğü (2018). (Son erişim: 22.06.2018) http://www.antalyakulturturizm.gov.tr/TR,68432/kultur-turizmi.html

Buehler R. \& Pucher J. (2012). Cycling to work in 90 large American cities: new evidence on the role of bike paths and lanes. Transportation, 39: 409-432. DOI 10.1007/s11116-011-9355-8

Elker C. (1999). Ulaşımın Diğer Sektörlerle Etkileşimi ve Ulaşım Politikaları. Gazi Üniversitesi Fen Bilimleri Enstitüsü Trafik Bülteni, Ankara, 11:18-21.

Ewing R. \& Cervero R. (2010). Travel and the built environment: a meta analysis. J. Am. Plan. Assoc. 76(3), 265294.

Google Earth (2021).

google.com/maps/place/Antalya/@36.8978553,30.5780206,57212m/data=!3m2!1e3!4b1!4m5!3m4!1s0x14c39aaedda dadc1:0x95c69f73f9e32e33!8m2!3d36.8968908!4d30.7133233

Heinen E., Van Wee B. \& Maat K. (2010). Commuting by bicycle: an overview of the literature. Transport Rev. 30 (1), 59-96. http://dx.doi.org/10.1080/01441640903187001

KENTGES (2010). Bütünleşik Kentsel Gelişme Stratejisi ve Eylem Planı (2010-2023). https://kentges.csb.gov.tr/ Erişim: Şubat 2021.

Lundberg B. \& Weber J. (2014). Non-motorized transport and university populations: an analysis of connectivity and network perceptions. Journal of Transport Geography 39 (2014) 165-178

Mansuroğlu S. \& Dağ V. (2019). Antalya Örneğinde Sürdürülebilir Kentiçi Ulaşımda Halkın Bisiklet Kullanımı ve Bisiklet Yollarına Yaklaşımlarının Belirlenmesi. Akdeniz Üniversitesi Bilimsel Araştırmalar Projesi (BAP) Sonuç Raporu (Basılmamış). Proje No: FBA-2018-3316, Antalya.

Mansuroğlu S. \& Dağ V. (2020). Antalya Örneğinde Turizm Kentlerinde Bisikletli Ulaşım Güzergahı Olanaklarının Değerlendirilmesi. Journal of Bartin Faculty of Forestry, 22(2), 341-353.

McBain C. \& Caulfield B. (2017). An Analysis of the Factors Influencing Journey Time Variation in the Cork Public Bike System. Sustainable Cities and Society https://doi.org/10.1016/j.scs.2017.09.030.

Mert K. (2007). Konya'da bisiklet ulaşımı-planlama ve uygulama sürecinin incelenmesi. Gazi Üniversitesi Fen Bilimleri Enstitüsü Trafik Planlaması ve Uygulaması Anabilim Dalı Yüksek Lisans Tezi, 112 s., Ankara. 
On Birinci Kalkınma Planı (2019-2023) (2019). sbb.gov.tr/wp-content/uploads/2019/07/OnbirinciKalkinmaPlani.pdf Erişim: Şubat 2021.

Öncü E. (1997). Kentiçi Ulaşımda 21. Yüzyll Perspektifi. Ulaşım-Trafik Kongresi, Ankara, 21-42.

Providelo J. K. \& Sanches, S. P. (2010). Roadway and traffic characteristics for bicycling. 12th WCTR (World Conference on Transport Research), July 11-15, 2010 - Lisbon, Portugal.

Schepers P., Twisk D., Fishman E., Fyhri A. \& Jensen A. (2017). The Dutch road to a high level of cycling safety. Safety Science 92 (2017) 264-273.

Stead D. \& Marshall S. (2001). The relationships between urban form and travel patterns. European Journal of Transport and Infrastructure Research 1(2):113-141.

Sun G. \& Zacharias J. (2017). Can bicycle relieve overcrowded metro? Managing short-distance travel in Beijing. Sustainable Cities and Society 35 (2017) 323-330

TUIK, 2019. Konularına Göre İstatistikler . http://tuik.gov.tr/UstMenu.do?metod=kategorist Erişim tarihi: 01.03.2019

Ulaştırma Özel İhtisas Komisyonu (1995). Kentiçi Ulaşım Alt Komisyonu Raporu. T.C. Başbakanlık Devlet Planlama Teşkilatı Müsteşarlığı,2388-451, Ankara, 2-11.

UTTA (1996). Antalya Büyükşshir Belediyesi Nazım Imar Planı-1/5000 Araştırma-Açıklama Raporu. UTTA Planlama, Projelendirme ve Danışmanlık Ltd. Şti., Ankara.

Van Wee B. (2002). Land-use and transport: Research and policy challenges. Journal of Transport Geography, vol. 10, no. 4, pp. 259-271.

Yavuz B. (2016). Sürdürülebilir Ulaşım Kapsamında Bisiklet Ulaşımının İzmir Bornova İlçesinde İrdelenmesi. Bahçeşehir Üniversitesi Fen Bilimleri Enstitüsü Kentsel Sistemler ve Ulaştırma Yönetimi Anabilim Dalı yüksek Lisans Tezi. 196s, İstanbul.

Yeşil M. \& Beyli K N. (2018). Mimarlık, Planlama ve Tasarımda Akademik Araştırmalar. Sürdürülebilir Ulaşımda bisikletin Yeri: Ordu Kenti Örneği. Gece Kitaplığı, ISBN: 978-605-288-389-1. Editör: Öğr. Gör. Dr. Çiğdem EREN.

Zhao P. (2014). The Impact of the Built Environment on Bicycle Commuting: Evidence from Beijing. Journal of Urban Studies 51(5) 1019-1037. 